\title{
An approach to assessing the possibility of diversifying the regional economy taking into account innovation activity
}

\author{
Mikhail Afanasiev ${ }^{1, *}$, Aleksander Kudrov $^{2}$, Maria Lysenkova ${ }^{1}$ \\ ${ }^{1}$ Central Economics and Mathematics Institute of the Russian Academy of Sciences (CEMI RAS), \\ Moscow, Russia \\ State Academic University for the Humanities (GAUGN), Moscow, Russia \\ ${ }^{2}$ Central Economics and Mathematics Institute of the Russian Academy of Sciences (CEMI RAS), \\ Moscow, Russia
}

\begin{abstract}
An approach to assessing the possibility of diversifying the regional economy is presented on the basis of the author's methodology for formation of recommendations for development of regions and sectors. The approach is based on regression analysis using an extended economic basis, including the characteristics of regional differentiation and innovative activity. On this basis, sectors can be identified, the development of which depends on the innovative activity of the regions. The estimates obtained make it possible to judge the influence of the characteristics of regional differentiation and innovative activity on development of such sectors. It is shown that innovative activity can contribute to diversification, if the region has a relatively high level of economic development. As a result of approbation of the offered approach, 20 sectors were identified, the production volume of which depends on the innovative activity of the regions aimed at creating international patent applications. It is shown that for each sector, the development of which depends on innovative activity, regions can be identified, where the growth of innovative activity can be accompanied by an increase in the volume of production of this sector and its appearance as a strong one. For the CONSTRUCTION sector, considered as an example, 17 regions have been identified that are priority for development of this sector and its transformation into a strong one.
\end{abstract}

\section{Introduction}

Two main theories describe the mechanism of knowledge creation and dissemination: localized specialization and economic diversification. The theory of localized specialization was first presented in detail in paper (Marshall, 1890). She argues that companies surrounded by others in the same industry will grow faster due to circulation of knowledge within the industry. This theory was developed in papers (Arrow, 1962; Romer, 1986),

\footnotetext{
* Corresponding author: mi.afan@yandex.ru
} 
while the opposite theory and empirical estimates are presented in papers (Blien, Wolf, 2006; Fuchs, 2011; Illy, Schwartz et al., 2011). According to this theory, companies benefit from being faced with a heterogeneous and diverse industry environment as new ideas come from the external environment. The mechanisms by which diversity leads to economic growth are commonly referred to as diversification.

Diversification defined as expanding the structure of the economy, is an important goal in all countries and is identified as one of the most important priorities for economic development. Development of unique specializations and using the potential for diversification is at the heart of the recently announced European Union strategy to promote economic development, growth in European regions and new industrial policies (EuropeanCommission, 2011a, 2011b; McCann, Ortega-Argiles, 2015). Oil exporters have also recognized the need for a diversification strategy, recognizing the limitations of oilbased growth and the need to find alternative ways to maintain and enhance national wealth (International Monetary Fund, 2015, 2016)

The following is an approach to diversification of the regional economy based on the author's methodology for formation of recommendations for development of regions and sectors using the characteristics of regional differentiation and innovative activity. On the basis of a regression analysis of the production volumes of the sectors of the economy, sectors were identified, the development of which depends on the innovative activity of the regions. Quantitative characteristics have been obtained that make it possible to judge the impact of regional innovation systems on development of such sectors. It is shown that influence of the regional innovation system can contribute to diversification if the region has a relatively high level of economic development.

\section{Methodology}

2.1. At the first stage of formation of recommendations, a correlation analysis of the components of the economic basis is carried out, including the characteristics of regional differentiation and indices of innovative activity. Description of the economic basis offered

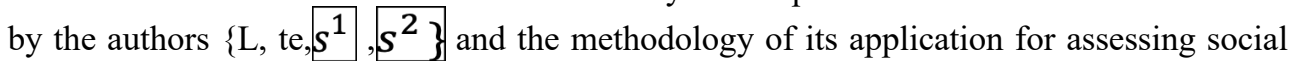
and economic development at the regional level are presented in (Aivazian, Afanasiev, Kudrov, 2018, 2020). The description of the indices of innovation activity used below, built on the basis of the stochastic frontier concept, is given in (Lysenkova, Afanasiev, 2020). To exclude the effects of multicollinearity when constructing regression models, it is necessary that the characteristics of the economic basis and the indices of innovative activity are statistically independent.

2.2. The second stage in formation of recommendations is the expansion of the economic basis due to an additional component - one of the indices of innovation activity. Extended economic basis $\left\{\mathrm{L}, \mathrm{te}, \widehat{s^{1}}, \widehat{\left.s^{2}, I N N\right\}}\right.$, including the index of innovative activity $I N N$, reflects not only the economic structure of the regional economy, but also the specifics of the innovative activity of the regions, focused on a specific result. At this stage, a regression analysis of the production volumes of each sector of the economy is carried out using the economic basis extended by including the innovation activity index. As estimates of production volumes, data on tax revenues by sectors of the economy can be used ${ }^{1}$, which allows us to characterize the structures of regional economies, including sectors oriented to both external and internal markets. The assumption that the volumes of tax revenues by sectors of the economy in the regions correctly reflect the proportions of production

\footnotetext{
${ }^{1}$ Data on tax receipts

https://www.nalog.ru/rn77/related_activities/statistics_and_analytics/forms/8826515/
} 
volumes is taken into account. If the index of innovative activity statistically depends on some components of the economic basis, then to prevent the effect of multicollinearity, it is advisable to use a modification of the index, cleared of the influence of these components.

Let's construct regressions of the form

$$
\ln T_{i j}=\text { const }_{i}+\beta 1_{i} \ln L_{j}+\beta 2_{i} t e_{j}+\beta 3_{i} s_{i}^{1}+\beta 4_{i} s_{i}^{2}+\beta 5_{i} I N N_{j}+\varepsilon_{i, j}(1)
$$

Here $\left[T_{i j}\right.$ - the volume of tax revenues from the sector $\bar{i}$ in the region $\bar{j} ; L_{j}$ - the scale of the region's economy $\bar{j}$ (the Rosstat indicator "number of economically active population" is used as a characteristic of the scale of the economy); $t e_{j}-$ assessment of the technical efficiency of regional production (Ayvazyan et al., 2018); $s_{i}^{1}$ — the index of industry specialization (the first main component of the GRP structure); $\sqrt{s_{i}^{2}}-$ industrialization index (the second main component of the GRP structure). When constructing the main components, the author's methodology and Rosstat indicators for the sectoral structure of GRP were used (Ayvazyan et al., 2016). INN — index of innovative activity (one of the author's indices used here is built on the basis of the concept of stochastic frontier according to data on international patent applications (TEMPZ), patent applications (TEPZ), granted patents (TEVP), newly developed production technologies (TETTCH) (Lysenkova, Afanasiev, 2020). $\sqrt{\varepsilon_{i, j}}$ - regression error.

Of the total of 82 sectors, those for which the parameter estimate $\beta 5_{i}$ is positive and significant at the $95 \%$ level. The volume of production in each of these sectors depends on the level of innovation activity of the regions, as determined by the INN index. Further, the focus is on these sectors of the economy.

2.3. At this stage, the level of compliance of the sector's production with the potential determined by the differentiation characteristics of the extended economic base is calculated. The regions that have a sufficient resource endowment, in the conditions of which one can expect the influence of innovative activity on the growth of the sector's production are identified.

Consider a specific sector of the economy $\boldsymbol{i}$ and the corresponding regression of the form (1). In accordance with the results obtained at the second stage of the study, we consider the sector for which the estimate of the factor $\beta 5_{i}$ is positive and significant at the $95 \%$ level. Let us sort the regions in ascending order of regression error values $\varepsilon_{i, j}$. Those regions for which the error $\varepsilon_{i, j}$ below zero, do not fully use their economic opportunities determined by the extended economic basis $\left\{\mathrm{L}, \mathrm{te}, \mathrm{s}^{1}, \sqrt{\left.s^{2}, I N N\right\}}\right.$. The growth of innovation activity in such regions does not have a sufficient economic basis for development of the sector. Therefore, it is difficult to expect that this growth will lead to a significant increase in production volumes of the economic sector of interest to us. Regions for which the error $\varepsilon_{i, j}$ is positive, exceed the level of development determined by the components of the extended economic base. Development potential determined by the extended economic base has been implemented in such regions. On this economic basis, an increase in the volume of production of the sector is possible due to the growth of innovative activity in the region. Based on the comparison of the regression errors, it is possible to assess how a particular region looks in relation to other regions in terms of the potential for the influence of its innovative activity on the growth of the sector's production. The characteristics of the extended economic base reflect the main economic features of the regional economy: scale, structure, efficiency, innovative activity. Therefore, the error $\varepsilon_{i, j}$ can be viewed in a broad sense as a characteristic of the resource provision of the region for development of the economic sector. A positive value for this score indicates that 
the region has sufficient resources to support the sector's output that matches the characteristics of the broader economic base. In this case, innovative activity becomes a priority source of growth in the sector's production and a factor of diversification.

2.4. The description of the structures of the strong sectors of regional economies is given. At first we will define an indicator $R C A_{c p}$ of the revealed comparative advantages:

$$
R C A_{c p}=\left(y_{c p} / \sum_{p} y_{c p}\right) /\left(\sum_{c} y_{c p} / \sum_{c, p} y_{c p}\right)
$$

where $y_{c p}$ - the volume of production of the sector $p$ of the economy of the region $c$; $R C A_{c p}$ - the ratio of the share of production from sector $p$ in the total volume of production from all sectors of the economy of the region $c$ to the share of production from sector $p$ in all regions in the volume of production from all sectors of the economy of all regions. According to (Hausmann, Klinger, 2006), the $R C A_{c p}$, indicator for which the condition of the lower constraint type is checked is used to identify comparative advantages in economies. Namely, if the value $R C A_{c p}$ is greater than or equal to one, then it is considered that the economy of the region $c$ has the revealed comparative advantages in the output of the sector $p$; otherwise, there are no identified comparative advantages:

$$
a_{c, p}= \begin{cases}1, \text { если } & R C A_{c p} \geq 1 ; \\ 0, \text { если } & R C A_{c p}<1 .\end{cases}
$$

Matrix $\mathbf{A}=\left(a_{c, p}\right)$ contains data on sectors of the economy that are developed in different regions at the level of revealed comparative advantages determined using expression (2). Lines of this matrix correspond to regions, columns - to sectors of economy. Vector $\left(a_{c, p_{1}}, \ldots, a_{c, p m}\right)$ we will call the structure of the strong sectors of the region's economy $c$.

2.5. Possibilities of production diversification are being considered. An assessment of the diversification of the structure of the strong sectors of the region's economy is the number of strong sectors. Thus, the diversification of the regional economy is associated with the emergence of a new strong sector in it. If the sector of interest to us is already strong in the regional economy, then the growth in the production volume of this sector will not lead to diversification. If the sector is not strong, then in the context of the characteristics of an extended economic base, two main development paths leading to diversification are possible.

a. The economic development of the region, as a result of which the sector becomes strong, not relying on the growth of the region's innovative activity. This option is available for any region where the sector is not strong.

b. Emergence of a new strong sector due to the growth of innovative activity. This option is available for a region, where the sector is not strong, with sufficient resources.

\section{Calculation results}

3.1. The correlation matrix of the components of the economic basis and indices of innovation activity is presented in Table 1 . Correlation analysis of 4 components of the economic basis and 4 indices of innovation activity shows:

- all components of the economic basis can be considered mutually independent; 
- the indices of innovation activity can be considered mutually independent (with the exception of the TEPZ and TEVP indices, the dependence of which is due to their specifics);

- each index of innovation activity is independent, or weakly dependent on the economic basis.

Table 1. Correlation matrix of components of the basis and indices of innovative activity built on the basis of 2015 data. Author's development.

\begin{tabular}{|c|c|c|c|c|c|c|c|c|}
\hline & $\mathbf{L}$ & te & s1 & s2 & TEMPZ & TEPZ & TEVP & ТЕТТСН \\
\hline $\mathbf{L}$ & 1 & 0.178 & -0.135 & 0.195 & 0.231 & 0.207 & 0.120 & 0.146 \\
\hline te & 0.178 & 1 & 0.202 & 0.238 & 0.120 & -0.200 & -0.193 & 0.214 \\
\hline s1 & -0.135 & 0.202 & 1 & $\begin{array}{c}-1,61 \mathrm{E}- \\
10 \\
\end{array}$ & -0.223 & -0.309 & -0.359 & -0.058 \\
\hline s2 & 0.195 & 0.238 & $\begin{array}{c}-1,61 \mathrm{E}- \\
10 \\
\end{array}$ & 1 & 0.398 & 0.056 & 0.146 & 0.167 \\
\hline TEMPZ & 0.231 & 0.120 & -0.223 & 0.398 & 1 & 0.047 & 0.067 & 0.405 \\
\hline TEPZ & 0.207 & -0.200 & -0.309 & 0.056 & 0.047 & 1 & 0.873 & 0.158 \\
\hline TEVP & 0.120 & -0.193 & -0.359 & 0.146 & 0.067 & 0.873 & 1 & 0.136 \\
\hline TETTCH & 0.146 & 0.214 & -0.058 & 0.167 & 0.405 & 0.158 & 0.136 & 1 \\
\hline
\end{tabular}

3.2. Table 2 presents the results of a regression analysis of tax revenues (in logarithms) by sector for the characteristics of the economic basis, extended, as an example, with the TEMPZ innovation activity index built on the basis of data on international patent applications.

Table 2. Sectors, the development of which depends on the innovative activity of regions according to 2019. Author's development.

\begin{tabular}{|c|c|c|c|c|c|c|c|c|}
\hline $\begin{array}{l}\text { Name of } \\
\text { the sector } \\
\text { of the } \\
\text { economy }\end{array}$ & $\begin{array}{l}\mathbf{N} \\
*\end{array}$ & $\mathbf{R}^{2}$ & const & $\boldsymbol{\beta 1 _ { j }}$ & $\boldsymbol{\beta \mathbf { 2 } _ { j }}$ & $\overline{\beta 3_{j}}$ & $\boldsymbol{\beta 4 _ { j }}$ & $\boldsymbol{\beta 5 _ { j }}$ \\
\hline (1) & (2) & (3) & (4) & (5) & (6) & (7) & (8) & (9) \\
\hline $\begin{array}{l}\text { Provision of } \\
\text { services in } \\
\text { the field of } \\
\text { oil and } \\
\text { natural gas } \\
\text { production }\end{array}$ & 66 & 0.468 & $\begin{array}{c}-6.314 \\
(-1.604)\end{array}$ & $\begin{array}{c}2.282 \\
(4.230)\end{array}$ & $\begin{array}{c}0.066 \\
(0.146)\end{array}$ & $\begin{array}{c}2.435 \\
(5.421)\end{array}$ & $\begin{array}{c}-0.658 \\
(-1.309)\end{array}$ & $\begin{array}{c}1.162 \\
(2.203)\end{array}$ \\
\hline $\begin{array}{l}\text { Manufactur } \\
\text { e of other } \\
\text { non-metallic } \\
\text { mineral } \\
\text { products }\end{array}$ & 80 & 0.617 & $\begin{array}{c}4.879 \\
(6.080)\end{array}$ & $\begin{array}{c}1.182 \\
(10.545)\end{array}$ & $\begin{array}{c}0.020 \\
(0.202)\end{array}$ & $\begin{array}{c}-0.189 \\
(-1.872)\end{array}$ & $\begin{array}{c}0.433 \\
(3.903)\end{array}$ & $\begin{array}{c}0.229 \\
(2.203)\end{array}$ \\
\hline $\begin{array}{c}\text { Other } \\
\text { production }\end{array}$ & 78 & 0.673 & $\begin{array}{c}4.547 \\
(5.130) \\
\end{array}$ & $\begin{array}{c}1.220 \\
(9.865) \\
\end{array}$ & $\begin{array}{c}-0.128 \\
(-1.186) \\
\end{array}$ & $\begin{array}{c}0.127 \\
(1.093) \\
\end{array}$ & $\begin{array}{c}0.434 \\
(3.516) \\
\end{array}$ & $\begin{array}{c}0.280 \\
(2.376) \\
\end{array}$ \\
\hline $\begin{array}{l}\text { Production } \\
\text { and } \\
\text { distribution } \\
\text { of gaseous } \\
\text { fuels }\end{array}$ & 78 & 0.469 & $\begin{array}{c}7.700 \\
(9.746)\end{array}$ & $\begin{array}{c}0.757 \\
(6.897)\end{array}$ & $\begin{array}{c}0.090 \\
(0.956)\end{array}$ & $\begin{array}{c}0.140 \\
(1.406)\end{array}$ & $\begin{array}{c}0.289 \\
(2.856)\end{array}$ & $\begin{array}{c}0.226 \\
(2.253)\end{array}$ \\
\hline
\end{tabular}


Continuation of Table 2.

\begin{tabular}{|c|c|c|c|c|c|c|c|c|}
\hline $\begin{array}{c}\text { Collection, } \\
\text { processing } \\
\text { and disposal } \\
\text { of waste; } \\
\text { processing } \\
\text { of } \\
\text { secondary } \\
\text { raw } \\
\text { materials }\end{array}$ & 79 & 0.801 & $\begin{array}{c}7.946 \\
(17.125)\end{array}$ & $\begin{array}{c}1.113 \\
(17.154)\end{array}$ & $\begin{array}{c}0.110 \\
(1.958)\end{array}$ & $\begin{array}{c}0.168 \\
(2.886)\end{array}$ & $\begin{array}{c}0.103 \\
(1.585)\end{array}$ & $\begin{array}{c}0.230 \\
(3.840)\end{array}$ \\
\hline $\begin{array}{c}\text { Constructio } \\
n\end{array}$ & 79 & 0.767 & $\begin{array}{c}7.212 \\
(12.778)\end{array}$ & $\begin{array}{c}1.139 \\
(14.428)\end{array}$ & $\begin{array}{c}0.090 \\
(1.321)\end{array}$ & $\begin{array}{c}0.228 \\
(3.235)\end{array}$ & $\begin{array}{c}0.158 \\
(1.991)\end{array}$ & $\begin{array}{c}0.274 \\
(3.767)\end{array}$ \\
\hline $\begin{array}{l}\text { Wholesale } \\
\text { and retail } \\
\text { trade; repair } \\
\text { of motor } \\
\text { vehicles and } \\
\text { motorcycles }\end{array}$ & 80 & 0.782 & $\begin{array}{c}7.257 \\
(16.591)\end{array}$ & $\begin{array}{c}1.056 \\
(17.286)\end{array}$ & $\begin{array}{c}0.168 \\
(3.167)\end{array}$ & $\begin{array}{c}0.046 \\
(0.840)\end{array}$ & $\begin{array}{c}0.022 \\
(0.367)\end{array}$ & $\begin{array}{c}0.159 \\
(2.806)\end{array}$ \\
\hline $\begin{array}{l}\text { Railway } \\
\text { transport } \\
\text { activities }\end{array}$ & 65 & 0.377 & $\begin{array}{c}1.231 \\
(0.500)\end{array}$ & $\begin{array}{c}1.242 \\
(3.552)\end{array}$ & $\begin{array}{c}0.305 \\
(1.103)\end{array}$ & $\begin{array}{c}1.297 \\
(4.866)\end{array}$ & $\begin{array}{c}-0.238 \\
(-0.728)\end{array}$ & $\begin{array}{c}0.593 \\
(2.121)\end{array}$ \\
\hline $\begin{array}{l}\text { Pipeline } \\
\text { transport } \\
\text { activities }\end{array}$ & 80 & 0.584 & $\begin{array}{c}5.290 \\
(5.563)\end{array}$ & $\begin{array}{c}1.184 \\
(8.919)\end{array}$ & $\begin{array}{c}0.292 \\
(2.530)\end{array}$ & $\begin{array}{c}0.400 \\
(3.348)\end{array}$ & $\begin{array}{c}-0.004 \\
(-0.033)\end{array}$ & $\begin{array}{c}0.261 \\
(2.116)\end{array}$ \\
\hline $\begin{array}{l}\text { Air and } \\
\text { space } \\
\text { transport } \\
\text { activities }\end{array}$ & 79 & 0.712 & $\begin{array}{c}4.893 \\
(8.754)\end{array}$ & $\begin{array}{c}1.092 \\
(14.012)\end{array}$ & $\begin{array}{c}0.113 \\
(1.674)\end{array}$ & $\begin{array}{c}0.170 \\
(2.418)\end{array}$ & $\begin{array}{c}0.169 \\
(2.183)\end{array}$ & $\begin{array}{c}0.154 \\
(2.102)\end{array}$ \\
\hline $\begin{array}{l}\text { Postal and } \\
\text { courier } \\
\text { activities }\end{array}$ & 80 & 0.742 & $\begin{array}{c}5.870 \\
(9.214)\end{array}$ & $\begin{array}{c}1.129 \\
(12.685)\end{array}$ & $\begin{array}{c}0.140 \\
(1.816)\end{array}$ & $\begin{array}{c}0.143 \\
(1.784)\end{array}$ & $\begin{array}{c}0.080 \\
(0.903)\end{array}$ & $\begin{array}{c}0.233 \\
(2.827)\end{array}$ \\
\hline $\begin{array}{l}\text { Activities of } \\
\text { hotels and } \\
\text { other places } \\
\text { for } \\
\text { temporary } \\
\text { residence }\end{array}$ & 80 & 0.745 & $\begin{array}{c}5.590 \\
(11.643)\end{array}$ & $\begin{array}{c}1.062 \\
(15.832)\end{array}$ & $\begin{array}{c}0.124 \\
(2.132)\end{array}$ & $\begin{array}{c}0.165 \\
(2.740)\end{array}$ & $\begin{array}{c}0.020 \\
(0.307)\end{array}$ & $\begin{array}{c}0.143 \\
(2.298)\end{array}$ \\
\hline $\begin{array}{l}\text { Activities in } \\
\text { the field of } \\
\text { telecommun } \\
\text { ications }\end{array}$ & 80 & 0.787 & $\begin{array}{c}-2.063 \\
(-2.405)\end{array}$ & $\begin{array}{c}1.783 \\
(14.893)\end{array}$ & $\begin{array}{c}0.113 \\
(1.089)\end{array}$ & $\begin{array}{c}0.129 \\
(1.197)\end{array}$ & $\begin{array}{c}0.226 \\
(1.908)\end{array}$ & $\begin{array}{c}0.288 \\
(2.590)\end{array}$ \\
\hline $\begin{array}{c}\text { Financial } \\
\text { and } \\
\text { insurance } \\
\text { activities }\end{array}$ & 80 & 0.800 & $\begin{array}{c}4.553 \\
(7.759)\end{array}$ & $\begin{array}{c}1.362 \\
(16.624)\end{array}$ & $\begin{array}{c}0.085 \\
(1.195)\end{array}$ & $\begin{array}{c}0.037 \\
(0.507)\end{array}$ & $\begin{array}{c}0.197 \\
(2.427)\end{array}$ & $\begin{array}{c}0.175 \\
(2.304)\end{array}$ \\
\hline $\begin{array}{c}\text { Financial } \\
\text { services } \\
\text { activities, } \\
\text { excluding } \\
\text { insurance } \\
\text { and pension } \\
\text { services }\end{array}$ & 79 & 0.740 & $\begin{array}{c}4.466 \\
(6.809)\end{array}$ & $\begin{array}{c}1.410 \\
(15.466)\end{array}$ & $\begin{array}{c}0.073 \\
(0.943)\end{array}$ & $\begin{array}{c}0.433 \\
(5.490)\end{array}$ & $\begin{array}{c}0.186 \\
(2.216)\end{array}$ & $\begin{array}{c}0.327 \\
(3.949)\end{array}$ \\
\hline $\begin{array}{l}\text { Real estate } \\
\text { activities }\end{array}$ & 80 & 0.878 & $\begin{array}{c}7.565 \\
(31.719)\end{array}$ & $\begin{array}{c}0.989 \\
(29.702)\end{array}$ & $\begin{array}{c}0.084 \\
(2.907)\end{array}$ & $\begin{array}{c}0.243 \\
(8.115)\end{array}$ & $\begin{array}{c}-0.004 \\
(-0.109)\end{array}$ & $\begin{array}{c}0.099 \\
(3.210)\end{array}$ \\
\hline
\end{tabular}




\begin{tabular}{|c|c|c|c|c|c|c|c|c|}
\hline $\begin{array}{l}\text { Professional } \\
\text {, scientific } \\
\text { and } \\
\text { technical } \\
\text { activities }\end{array}$ & 80 & 0.853 & $\begin{array}{c}7.805 \\
(24.761)\end{array}$ & $\begin{array}{c}0.923 \\
(20.960)\end{array}$ & $\begin{array}{c}0.055 \\
(1.448)\end{array}$ & $\begin{array}{c}0.207 \\
(5.222)\end{array}$ & $\begin{array}{c}0.048 \\
(1.101)\end{array}$ & $\begin{array}{c}0.078 \\
(1.902)\end{array}$ \\
\hline $\begin{array}{c}\text { Administrati } \\
\text { ve activities } \\
\text { and related } \\
\text { additional } \\
\text { services }\end{array}$ & 79 & 0.816 & $\begin{array}{c}5.671 \\
(12.978)\end{array}$ & $\begin{array}{c}1.021 \\
(16.732)\end{array}$ & $\begin{array}{c}0.163 \\
(3.050)\end{array}$ & $\begin{array}{c}0.175 \\
(3.172)\end{array}$ & $\begin{array}{c}0.069 \\
(1.138)\end{array}$ & $\begin{array}{c}0.119 \\
(2.090)\end{array}$ \\
\hline Education & 80 & 0.764 & $\begin{array}{c}4.273 \\
(10.312)\end{array}$ & $\begin{array}{c}1.095 \\
(18.929)\end{array}$ & $\begin{array}{c}0.068 \\
(1.351)\end{array}$ & $\begin{array}{c}0.169 \\
(3.243)\end{array}$ & $\begin{array}{c}0.126 \\
(2.190)\end{array}$ & $\begin{array}{c}0.170 \\
(3.170)\end{array}$ \\
\hline $\begin{array}{l}\text { Activities in } \\
\text { the field of } \\
\text { health and } \\
\text { social } \\
\text { services }\end{array}$ & 80 & 0.716 & $\begin{array}{c}2.534 \\
(4.960)\end{array}$ & $\begin{array}{c}1.138 \\
(15.953)\end{array}$ & $\begin{array}{c}0.087 \\
(1.407)\end{array}$ & $\begin{array}{c}0.152 \\
(2.366)\end{array}$ & $\begin{array}{c}0.073 \\
(1.034)\end{array}$ & $\begin{array}{c}0.183 \\
(2.758)\end{array}$ \\
\hline
\end{tabular}

* number of regions with non-zero tax revenue from this sector.

Column (1) of Table 2 shows the names of the sectors, the production volumes of which in the regions depend on the value of the TEMPZ innovation activity index built according to the data for 2019 on international patent applications. Column (2) for each sector indicates the number of observations for constructing the regression (the number of regions with non-zero tax revenues from this sector). Column (3) - coefficient of determination $\mathrm{R}^{2}$ . Column (4) - the estimate of the constant in the regression, in brackets t-statistic. Column (5) - estimation of the regression coefficient at the logarithm of the economically active population and t-statistics. Column (6) - estimation of the regression coefficient when the index of technical efficiency regional production and t-statistics. Column (7) evaluation of the regression coefficient at the first principal component of the GRP structure and t-statistics. Column (8) - estimation of the regression coefficient at the second main component of the GRP structure and t-statistics. Column (9) - estimation of the regression coefficient at the index of the innovative activity TEMPZ and t-statistics. The coefficient of determination $\mathrm{R}^{2}$ for almost each of the 20 sectors of the economy is quite high. This means that the used basis of characteristics of regional differentiation, extended by the author's index TEMPZ $i$, quite well explains the specifics of the production volumes of the sectors.

At this stage of the study, 20 sectors of the economy have been identified, the development of which depends on the innovative activity of the region when creating international patent applications. By formulating international patent applications and demonstrating activity in this area, the regions influence development of each of these 20 sectors. It follows from the simulation results that one of the ways to develop each of these sectors is to increase the scale of the economy, develop specialization or industrialization, and increase productivity. Depending on the components of the economic basis for which significant estimates of the regression coefficients are observed (1). Another way is connected with realization of the potential of innovative activity. If we replace the TEMPZ index with another index of innovative activity, we get a list of sectors, the output of which depends on the innovative activity of the region when creating the corresponding result of innovative activity.

3.3. The CONSTRUCTION sector is one of the sectors, the production volume of which depends on the innovative activity of the region. Let us consider the estimates of the regression errors (1) for the "Construction" sector of the economy. 
Table 3. CONSTRUCTION sector: estimates based on 2019 data. Author's development.

\begin{tabular}{|c|c|c|c|c|}
\hline Region & $\begin{array}{c}\text { Ranking } \\
\text { order }\end{array}$ & $\begin{array}{c}\text { Error } \\
\text { estimation }\end{array}$ & $\begin{array}{c}\text { Number of } \\
\text { strong sectors }\end{array}$ & $\begin{array}{c}1 \text { - strong sector, } \\
\text { otherwise - 0 }\end{array}$ \\
\hline (1) & (2) & (3) & (4) & (5) \\
\hline $\begin{array}{l}\text { Chechen } \\
\text { Republic* }\end{array}$ & 1 & -10 & 13 & 0 \\
\hline $\begin{array}{l}\text { The Republic of } \\
\text { Ingushetia* }\end{array}$ & 2 & -2.532 & 15 & 0 \\
\hline $\begin{array}{c}\text { The Republic of } \\
\text { Dagestan* }\end{array}$ & 3 & -1.482 & 19 & 0 \\
\hline Kursk region* & 4 & -1.087 & 22 & 0 \\
\hline $\begin{array}{l}\text { Kabardino- } \\
\text { Balkar } \\
\text { Republic* }\end{array}$ & 5 & -1.043 & 17 & 0 \\
\hline $\begin{array}{c}\text { Zabaykalsky } \\
\text { Territory* }\end{array}$ & 6 & -1.027 & 19 & 0 \\
\hline Tyumen region* & 7 & -0.897 & 8 & 0 \\
\hline Tyva Republic* & 8 & -0.783 & 17 & 0 \\
\hline $\begin{array}{c}\text { The Republic of } \\
\text { Buryatia* }\end{array}$ & 9 & -0.771 & 25 & 0 \\
\hline $\begin{array}{c}\text { The Republic of } \\
\text { Sakha } \\
\text { (Yakutia)* }\end{array}$ & 10 & -0.756 & 11 & 0 \\
\hline $\begin{array}{c}\text { Belgorod } \\
\text { region* }\end{array}$ & 11 & -0.75 & 24 & 0 \\
\hline $\begin{array}{c}\text { Republic of } \\
\text { North Ossetia - } \\
\text { Alania * } \\
\end{array}$ & 12 & -0.704 & 14 & 0 \\
\hline $\begin{array}{c}\text { The Republic of } \\
\text { Khakassia* }\end{array}$ & 13 & -0.673 & 22 & 0 \\
\hline $\begin{array}{c}\text { Jewish } \\
\text { Autonomous } \\
\text { Region* } \\
\end{array}$ & 14 & -0.67 & 21 & 0 \\
\hline $\begin{array}{c}\text { Krasnoyarsk } \\
\text { Territory* }\end{array}$ & 15 & -0.648 & 15 & 0 \\
\hline $\begin{array}{l}\text { Tambov } \\
\text { Region* }\end{array}$ & 16 & -0.525 & 28 & 0 \\
\hline $\begin{array}{l}\text { Kemerovo } \\
\text { Region* }\end{array}$ & 17 & -0.406 & 20 & 0 \\
\hline $\begin{array}{l}\text { Ulyanovsk } \\
\text { Region* }\end{array}$ & 18 & -0.363 & 25 & 0 \\
\hline $\begin{array}{c}\text { The Republic of } \\
\text { Kalmykia* }\end{array}$ & 19 & -0.352 & 14 & 0 \\
\hline Irkutsk Region* & 20 & -0.343 & 15 & 0 \\
\hline Rostov Region* & 21 & -0.331 & 33 & 0 \\
\hline $\begin{array}{l}\text { Kostroma } \\
\text { Region* }\end{array}$ & 22 & -0.323 & 33 & 0 \\
\hline $\begin{array}{l}\text { Orenburg } \\
\text { Region* }\end{array}$ & 23 & -0.315 & 6 & 0 \\
\hline $\begin{array}{l}\text { The Republic of } \\
\text { Bashkortostan* }\end{array}$ & 24 & -0.312 & 17 & 0 \\
\hline
\end{tabular}


Continuation of Table 3.

\begin{tabular}{|c|c|c|c|c|}
\hline $\begin{array}{c}\text { The Republic of } \\
\text { Karelia * }\end{array}$ & 25 & -0.302 & 26 & 0 \\
\hline $\begin{array}{c}\text { The Mari El } \\
\text { Republic* }\end{array}$ & 26 & -0.28 & 31 & 0 \\
\hline Amur Region* & 27 & -0.217 & 17 & 0 \\
\hline Samara Region* & 28 & -0.2 & 20 & 0 \\
\hline $\begin{array}{c}\text { The Republic of } \\
\text { Mordovia* }\end{array}$ & 29 & -0.2 & 15 & 0 \\
\hline $\begin{array}{l}\text { The Udmurt } \\
\text { Republic* }\end{array}$ & 30 & -0.182 & 15 & 0 \\
\hline Kaluga Region* & 31 & -0.177 & 29 & 0 \\
\hline $\begin{array}{c}\text { Arkhangelsk } \\
\text { Region* } \\
\end{array}$ & 32 & -0.154 & 20 & 0 \\
\hline $\begin{array}{c}\text { The Republic of } \\
\text { Tatarstan* }\end{array}$ & 33 & -0.112 & 13 & 0 \\
\hline Penza Region* & 34 & -0.1 & 26 & 0 \\
\hline Kurgan Region* & 35 & -0.091 & 26 & 0 \\
\hline $\begin{array}{c}\text { The Karachay- } \\
\text { Cherkess } \\
\text { Republic } \\
\end{array}$ & 36 & -0.079 & 27 & 1 \\
\hline $\begin{array}{c}\text { The Republic of } \\
\text { Adygea* }\end{array}$ & 37 & -0.062 & 22 & 0 \\
\hline $\begin{array}{l}\text { The Chuvash } \\
\text { Republic }\end{array}$ & 38 & -0.057 & 40 & 1 \\
\hline Lipetsk Region & 39 & -0.044 & 36 & 1 \\
\hline Pskov Region & 40 & 0.015 & 35 & 1 \\
\hline $\begin{array}{l}\text { Vladimir } \\
\text { Region }\end{array}$ & 41 & 0.043 & 37 & 1 \\
\hline Altai Territory & 42 & 0.063 & 33 & 1 \\
\hline $\begin{array}{c}\text { Chelyabinsk } \\
\text { Region** }\end{array}$ & 43 & 0.089 & 35 & 0 \\
\hline Tver Region** & 44 & 0.09 & 42 & 0 \\
\hline Tula Region & 45 & 0.109 & 34 & 1 \\
\hline $\begin{array}{l}\text { Volgograd } \\
\text { Region** }\end{array}$ & 46 & 0.129 & 17 & 0 \\
\hline Oryol Region & 47 & 0.134 & 30 & 1 \\
\hline $\begin{array}{c}\text { Tomsk Region } \\
* *\end{array}$ & 48 & 0.147 & 10 & 0 \\
\hline Kirov Region & 49 & 0.153 & 35 & 1 \\
\hline $\begin{array}{c}\text { Omsk Region } \\
* *\end{array}$ & 50 & 0.164 & 17 & 0 \\
\hline $\begin{array}{c}\text { Perm } \\
\text { Territory** } \\
\end{array}$ & 51 & 0.179 & 20 & 0 \\
\hline $\begin{array}{c}\text { Saratov } \\
\text { Region** }\end{array}$ & 52 & 0.219 & 21 & 0 \\
\hline $\begin{array}{l}\text { Stavropol } \\
\text { Territory }\end{array}$ & 53 & 0.232 & 23 & 1 \\
\hline
\end{tabular}


Continuation of Table 3.

\begin{tabular}{|c|c|c|c|c|}
\hline$\underset{* *}{\text { Sakhalin Region }}$ & 54 & 0.263 & 18 & 0 \\
\hline $\begin{array}{l}\text { Novgorod } \\
\text { Region }\end{array}$ & 55 & 0.268 & 32 & 1 \\
\hline $\begin{array}{l}\text { Voronezh } \\
\text { Region }\end{array}$ & 56 & 0.279 & 34 & 1 \\
\hline Bryansk Region & 57 & 0.304 & 31 & 1 \\
\hline $\begin{array}{l}\text { Nizhny } \\
\text { Novgorod } \\
\text { Region** }\end{array}$ & 58 & 0.31 & 24 & 0 \\
\hline $\begin{array}{c}\text { Ryazan } \\
\text { Region** }\end{array}$ & 59 & 0.347 & 16 & 0 \\
\hline $\begin{array}{l}\text { Astrakhan } \\
\text { Region** }\end{array}$ & 60 & 0.364 & 9 & 0 \\
\hline $\begin{array}{c}\text { Primorsky } \\
\text { Krai** }^{* *}\end{array}$ & 61 & 0.397 & 26 & 0 \\
\hline $\begin{array}{l}\text { Krasnodar } \\
\text { Territory }\end{array}$ & 62 & 0.406 & 27 & 1 \\
\hline Ivanovo region & 63 & 0.412 & 28 & 1 \\
\hline $\begin{array}{l}\text { Yaroslavl } \\
\text { Region*** }\end{array}$ & 64 & 0.493 & 25 & 0 \\
\hline $\begin{array}{c}\text { Kaliningrad } \\
\text { Region** }\end{array}$ & 65 & 0.536 & 15 & 0 \\
\hline $\begin{array}{l}\text { Novosibirsk } \\
\text { Region }\end{array}$ & 66 & 0.6 & 39 & 1 \\
\hline $\begin{array}{l}\text { Murmansk } \\
\text { Region** }\end{array}$ & 67 & 0.603 & 17 & 0 \\
\hline Altai Republic & 68 & 0.64 & 30 & 1 \\
\hline $\begin{array}{l}\text { Leningrad } \\
\text { Region*** }\end{array}$ & 69 & 0.75 & 14 & 0 \\
\hline St. Petersburg** & 70 & 0.752 & 23 & 0 \\
\hline $\begin{array}{l}\text { Sverdlovsk } \\
\text { Region }\end{array}$ & 71 & 0.797 & 30 & 1 \\
\hline $\begin{array}{c}\text { Khabarovsk } \\
\text { Territory }\end{array}$ & 72 & 0.876 & 21 & 1 \\
\hline Vologda Region & 73 & 0.882 & 25 & 1 \\
\hline $\begin{array}{l}\text { Chukotka } \\
\text { Autonomous } \\
\text { District }\end{array}$ & 74 & 1.103 & 13 & 1 \\
\hline $\begin{array}{l}\text { Kamchatka } \\
\text { Territory }\end{array}$ & 75 & 1.136 & 23 & 1 \\
\hline Moscow Region & 76 & 1.265 & 39 & 1 \\
\hline $\begin{array}{l}\text { The Komi } \\
\text { Republic }\end{array}$ & 77 & 1.398 & 14 & 1 \\
\hline $\begin{array}{l}\text { Magadan } \\
\text { Region }\end{array}$ & 78 & 1.429 & 23 & 1 \\
\hline $\begin{array}{l}\text { Smolensk } \\
\text { Region }\end{array}$ & 79 & 1.523 & 31 & 1 \\
\hline
\end{tabular}


Continuation of Table 3 .

\begin{tabular}{|c|c|c|c|c|} 
Moscow & 80 & 1.83 & 24 & 1 \\
\hline
\end{tabular}

** - a region, where the sector can become strong due to both economic growth and innovative activity of the regions; * - a region in which the sector can become strong due to economic growth.

Column (1) of this table contains the names of the regions. Column (2) shows the region number in ascending order of the error $\varepsilon_{i, j}$. Column (3) of Table 3 presents the error $\varepsilon_{i, j}$ values.

3.4 Column (4) of Table 3 indicates the number of strong sectors in the structure of the region's economy, that is, the assessment of economic diversification. The most diversified (with more than 35 strong sectors) are regional economies: Tver Region - 42; the Chuvash Republic - 40; Moscow Region - 39; Novosibirsk Region - 39; Vladimir Region - 37; Lipetsk Region - 36. The least diversified (with less than 10 strong sectors) are regional economies: Astrakhan Region - 9; Tyumen Region - 8; Orenburg Region - 6.

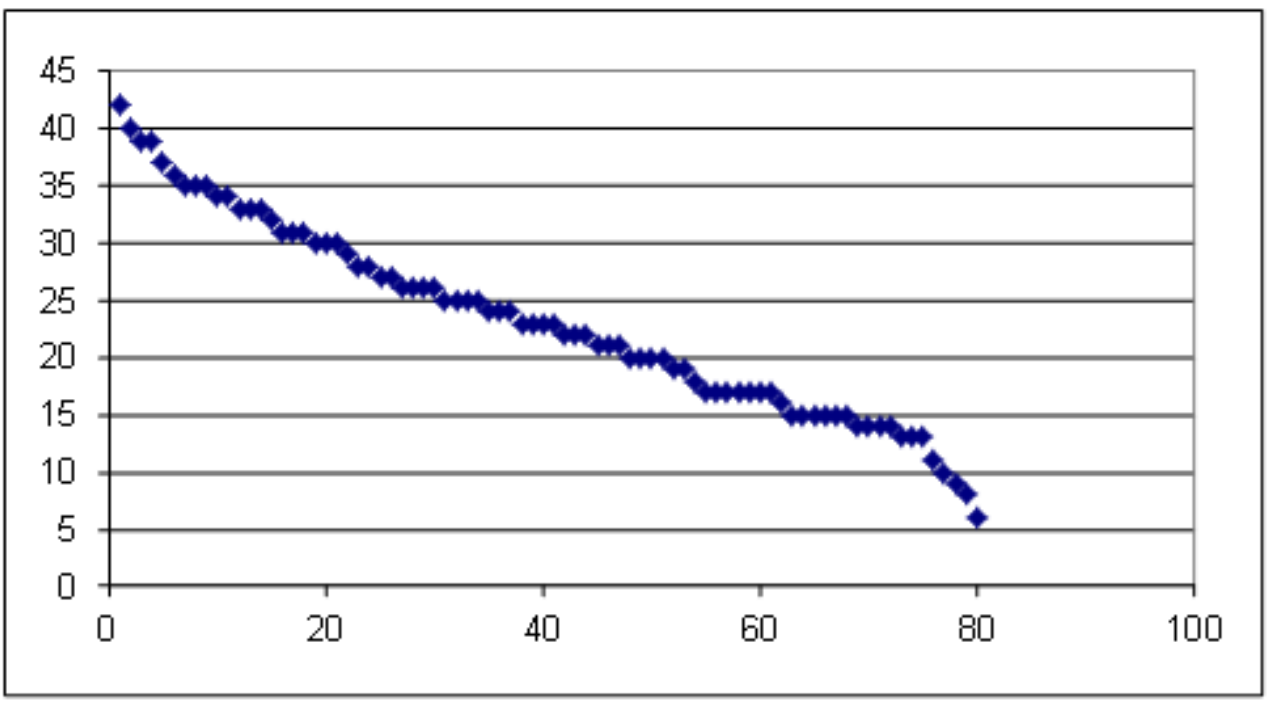

Fig. 1. Distribution of the number of strong sectors by region. Author's development.

Fig. 1 shows the distribution of strong sectors by region. The abscissa is the region number; the ordinate is the number of strong sectors sorted in descending order.

3.5 Column (5) of Table 3, as an example, provides estimates of the revealed comparative advantages of the CONSTRUCTION sector for different regions. It is indicated in which regions the CONSTRUCTION sector has identified comparative advantages and is strong (value 1), and in which it is not (value 0). The estimates obtained indicate that the CONSTRUCTION sector according to the data of 2019 is strong in the economy of 27 regions. In these regions, the growth in the volume of production in this sector will no longer lead to diversification of the structure of the economy. For 53 regions, the CONSTRUCTION sector is not strong. For these regions, diversification of the economy is possible due to the growth of the production volume of this sector and its transformation into a strong sector. 


\section{Discussion}

It is noteworthy that in 35 regions with the lowest error $\varepsilon_{i, j}$ estimates (region numbers in column (2) 1 to 35) CONSTRUCTION sector is not strong. Negative value of estimate for error $\varepsilon_{i, j}$ for these regions indicates that they have not reached the level of economic development corresponding to their characteristics of differentiation and have insufficient resource provision. In conditions of a relatively low level of economic development, in these regions, innovative activity does not have the necessary economic basis and cannot lead to a significant increase in the volume of production of the sector. The possibility of turning the CONSTRUCTION sector into a strong sector for such regions, marked in Table 3 with a "*", is associated with an increase in the scale of the economy, the development of manufacturing industries and an increase in multifactor productivity.

In the economies of 10 regions with the highest values of the regression errors (region numbers in column (2) from 71 to 80 ), the CONSTRUCTION sector is strong. Moreover, in each of these regions, the level of production volumes in the CONSTRUCTION sector is ensured, corresponding to their characteristics of differentiation and sufficient to implement the potential of innovative activity. Table 4 shows examples of some large construction projects that rely on the innovative capabilities of the regions. Including, for competencies related to the construction of high-rise buildings and use of 3D printers. However, there will be no change in the structure of the strong sectors of these 10 regions due to the growth in the volume of production in the CONSTRUCTION sector. The same can be said about 13 other regions (in column (2) their numbers are in the range from 36 to 68), in which the CONSTRUCTION sector is strong. It can be expected that the growth of the sector's production in these 13 regions, which does not lead to diversification, will be ensured both by the economic development of the region and by innovative activity.

For diversification based on the transformation of the CONSTRUCTION sector into a strong one, the most promising are the regions marked in Table 3 with "**", where this sector is not strong, with positive estimates of the regression errors (1). In these regions, the CONSTRUCTION sector can become strong due to both economic growth and innovative activity of the regions.

Table 4. Large projects in the Construction sector for regions with the highest estimates of regression errors.

\begin{tabular}{|c|c|}
\hline Region name & Large projects in the Construction sector \\
\hline Moscow $^{2}$ & $\begin{array}{r}\text { Design and construction of sections of the road network of the South- } \\
\text { East Expressway and the South Road } \\
\text { The cost is 138.7 billion rubles. Deadline is 2019-2023 }\end{array}$ \\
\cline { 2 - 2 } & $\begin{array}{c}\text { Execution of works within the framework of the III stage of construction } \\
\text { of the North-East Expressway } \\
\text { The cost is 52.0 billion rubles. Deadline is 2019-2022 }\end{array}$ \\
\hline The Komi & $\begin{array}{c}\text { Construction works at gas distribution facilities in the Komi Republic } \\
\text { under the Russian Regions Gasification Program } \\
\text { The cost is 7.18 billion rubles. }\end{array}$ \\
\hline
\end{tabular}

\footnotetext{
${ }^{2}$ Source: Top 10 government construction contracts in 2019

https://infraone.ru/sites/default/files/analitika/2019/stroitelstvo_2019_infraone_research.pdf

${ }^{3}$ Source: Portal "Government spending" https://spending.gov.ru
} 
Continuation of Table 4.

\begin{tabular}{|c|c|}
\hline \multirow[t]{2}{*}{ Moscow Region ${ }^{4}$} & $\begin{array}{c}\text { Construction and reconstruction of sections of M-5 Ural highway on the } \\
\text { bypass section of the Oktyabrsky settlement with a bridge across the } \\
\text { Moskva River } \\
\text { The cost is } 25.2 \text { billion rubles. Deadline is 2019-2023 }\end{array}$ \\
\hline & $\begin{array}{c}\text { Construction and reconstruction of M-5 Ural highway on Ulyanino - } \\
\text { Nepetsino section. } \\
\text { The cost is } 15.4 \text { billion rubles. Deadline is } 2019-2023\end{array}$ \\
\hline $\begin{array}{l}\text { Kamchatka } \\
\text { Territory }\end{array}$ & $\begin{array}{c}\text { Creation of the international resort "Three Volcanoes" in the Kamchatka } \\
\text { Territory. } \\
\text { The cost is } 39.2 \text { billion rubles. }\end{array}$ \\
\hline
\end{tabular}

\section{Conclusion}

An approach to formation of recommendations for development of regions and sectors of the economy, taking into account innovative activity, is offered. The approach is based on the method of regression analysis using an extended economic basis.

Approbation of the approach confirmed the possibility of identifying a set of sectors of the economy, the volume of production of which in the region depends on innovative activity. As an example, 20 sectors were identified, the volume of production of which depends on the innovative activity of regions aimed at creating international patent applications.

It is shown that for each sector, the development of which depends on innovative activity, regions can be identified, where the growth of innovative activity can be accompanied by an increase in the volume of production of this sector and its appearance as a strong one. For the CONSTRUCTION sector, considered as an example, 17 regions have been identified that are priority for development of this sector and its transformation into a strong one.

\section{References}

1. S. A. Aivazian, M. Yu. Afanasiev, A. V. Kudrov, Metod klasterizacii regionov RF $s$ uchetom otraslevoj struktury VRP, 41 (2016)

2. S. A. Aivazian, M. Yu. Afanasiev, A. V. Kudrov, Metod sravneniya regionov RF po ocenkam tekhnicheskoj effektivnosti s uchetom struktury proizvodstva, 54 (2018)

3. S. A. Aivazian, M. Yu. Afanasiev, A. V. Kudrov, Methodology of socio-economic development assessment given the characteristics of regional differentiation (2020)

4. S. A. Aivazian, M. Yu. Afanasiev, A. V. Kudrov, Indicators of Regional Development Using Differentiation Characteristics, 14 (2018)

5. K. J. Arrow, The economic implications of learning by doing, The Review of Economic Studies, 29 (1962)

6. U. Blien, K. Wolf, Local employment growth in West Germany: A dynamic panel approach, Labour Economics, 13 (2006)

7. European Commission (2012a), A stronger European Industry for Growth and Economic Recovery, Green paper and COM documents, COM (2012)

\footnotetext{
${ }^{4}$ Source: Top 10 government construction contracts in 2019

https://infraone.ru/sites/default/files/analitika/2019/stroitelstvo_2019_infraone_research.pdf

${ }^{5}$ Source: Top 10 government construction contracts in 2019

https://infraone.ru/sites/default/files/analitika/2019/stroitelstvo_2019_infraone_research.pdf
} 
8. European Commission (2011b), Cohesion Policy 2014-2020: Investing in growth and jobs, Green paper and COM documents, COM (2011)

9. M. Fuchs, The determinants of local employment dynamics in Western Germany (2011)

10. R. Hausmann, B. Klinger, Structural transformation and patterns of comparative advantage in the product space (2006)

11. A. Illy, M. Schwartz, C. Hornych, M. Rosenfeld, Local economic structure and sectoral employment growth in German cities (2011)

12. Long-Run Growth and Macroeconomic Stability in Low-Income Countries-The Role of Structural Transformation and Diversification. International Monetary Fund Staff Policy Paper, International Monetary Fund (2015). Access mode: https://www.imf.org/external/np/res/dfidimf/diversification.htm

13. Economic Diversification in Oil-exporting Arab countries, Annual Meeting of Arab Ministers of Finance, International Monetary Fund (2016). Access mode: https://www.imf.org/en/Publications/Policy-Papers/Issues/2016/12/31/EconomicDiversification-in-Oil-Exporting-Arab-Countries-PP5038

14. M. Lysenkova, M. Afanasiev, Comparative analysis of regional innovative development indexes in the space of expert-defined characteristics of regional differentiation (2020)

15. A. Marshall, Principles of Economics (1890)

16. P. McCann, R. Ortega-Argiles, Smart Specialization, Regional Growth and Applications to European Union Cohesion Policy, Regional Studies (2015)

17. P. M. Romer, Increasing returns and long-run growth, Journal of Political Economy, 94 (1986) 